\title{
Utility of the Transition Phase in Earplugs of the North Pacific Common Minke Whale as an Indicator of Age at Sexual Maturity
}

\author{
Hikari Maeda ${ }^{*}$, Yoshihiro Fujise ${ }^{2}$, Toshiya Kishiro3 ${ }^{3}$, Hidehiro Kato ${ }^{4}$ \\ ${ }^{1}$ National Research Institute of Far Seas Fisheries, Japan Fisheries Research and Education Agency, Yokohama, Japan \\ ${ }^{2}$ The Institute of Cetacean Research, Tokyo, Japan \\ ${ }^{3}$ Headquarters, Japan Fisheries Research and Education Agency, Yokohama, Japan \\ ${ }^{4}$ Tokyo University of Marine Science and Technology, Tokyo, Japan \\ Email: *hikarim@affrc.go.jp
}

How to cite this paper: Maeda, H., Fujise, Y., Kishiro, T. and Kato, H. (2017) Utility of the Transition Phase in Earplugs of the North Pacific Common Minke Whale as an Indicator of Age at Sexual Maturity. Open Journal of Animal Sciences, 7, 414-424. https://doi.org/10.4236/ojas.2017.74032

Received: May 19, 2017

Accepted: September 22, 2017

Published: September 25, 2017

Copyright (c) 2017 by authors and Scientific Research Publishing Inc. This work is licensed under the Creative Commons Attribution International License (CC BY 4.0).

http://creativecommons.org/licenses/by/4.0/

\begin{abstract}
Whale age at sexual maturity is one of the most important biological parameters that can be used in stock management and population analysis. Earplugs have been widely used as an indicator of age among rorquals. It has also been accepted that the transition phase in the earplug can be used as an indicator of age at sexual maturity in fin whales, sei whales, and Antarctic minke whales. This study aimed to provide further insight into the utility of the transition phase as an indicator of age at sexual maturity in the North Pacific common minke whales, which has not yet been clarified. The relationship between sexual maturity and transition phase in earplugs was examined using 981 readable earplugs from common minke whales that were sampled at the JARPN and JARPN II scientific permit survey platform in the western North Pacific from 1994 to 2011. The transition phase was recognized in 53.2\% of mature males and in $58.6 \%$ of mature females. Most whales in which the transition phase was recognized in the earplug were sexually mature. A significant correlation was found between the number of corpora and time after sexual maturation, as revealed by the transition phase, demonstrating that the transition phase is a valid indicator of age at sexual maturity in common minke whales. However, it was difficult to recognize the transition phase in whales that had recently attained sexual maturity because insufficient time had elapsed since its formation. To avoid potential bias, the use of earplugs as an indicator of age should be restricted to whales more than 12 years old.
\end{abstract}

\section{Keywords}

Common Minke Whale, Balaenoptera acutorostrata, Earplug, Age at Sexual Maturity, Transition Phase 


\section{Introduction}

Information on whale age is of key importance for estimating life-history parameters that can be used for stock management. To obtain data on age, it is necessary to identify characteristics that represent the age of an individual. Earplugs have been widely used to determine age among rorqual species [1] [2]; characteristics of whale earplugs in relation to animal age have been discussed in detail by Purves [3]. The earplug accumulates in the external auditory meatus [4] and comprises a core and outer covering [3] [5] (Figure 1). The auditory meatus is once closed just beneath the epidermis, and the earplug is never shed throughout the whale's lifespan. The outer covering of the earplug is secreted by epithelial cells in the external auditory meatus, whereas the core, which comprises concentric light and dark laminae, is secreted by papillae on the surface of the glove finger [3]. The light and dark layers are formed during the feeding and breeding periods, respectively [6]. Histological observations of fin whale (Balaenoptera physalus) earplugs have indicated that fat content tends to be lower in the dark layer and higher in the light layer [6]. Many baleen whales migrate between breeding locations in low-latitude waters (winter) and feeding locations in high-latitude waters (summer); this migration occurs once every year and is reflected in earplug growth layers, with a pair of dark and light layers representing 1 year [1] [6] [7] [8] [9]. Other features of the earplug include the neonatal line, which is formed at birth [10] in the apical portion of the core (Figure 1).

However, age reading from the earplugs of the North Pacific common minke whale ( $B$. acutorostrata) is generally believed to be difficult and impractical because of their softness and poor formation of growth layers. Considering the characteristics of earplugs, Maeda et al. [11] addressed the technical development of sampling called the gelatinized extraction method, which prevented damage to earplugs at the collection stage and was useful for improving age readability, especially in younger whales. From these studies, the readability of common minke whales was improved compared with that from commercial whaling because of careful collection and efforts in the technical development of earplug sampling. Furthermore, Maeda et al. [12] reported that earplugs of

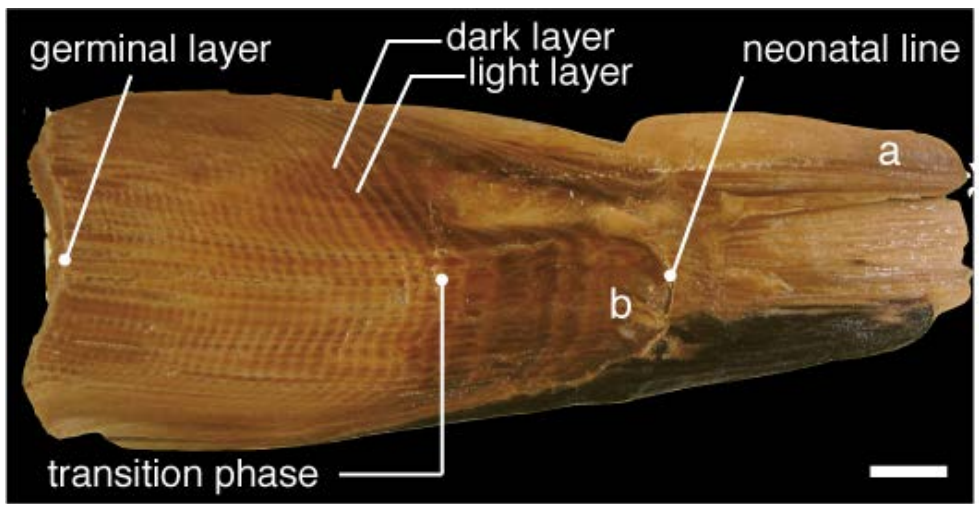

Figure 1. Bisected surface of an earplug of a fin whale (age $=36$ years, age at $\mathrm{Tp}=7$ years), a: outer covering; b: core with growth layers. Scale bar: $10 \mathrm{~mm}$. 
common minke whales in the western North Pacific were considered useful as a valid age tool.

More than a whale's age can be inferred from the earplug. Lockyer [8] examined fin whales from the southern hemisphere and observed a distinctly spaced growth layer that diminished suddenly, which was called the transition phase (Tp) (Figure 1). This Tp in the earplug, where widely spaced growth layers abruptly become much closer together, indicates the age at sexual maturity and is believed to be linked with changes in the skull's growth rate after sexual maturity [13] [14]. The presence of $\mathrm{Tp}$ has been reported for fin whales in the southern hemisphere [8] and Iceland [15] [16]; for sei whales (B. borealis) in the southern hemisphere [13], North Pacific [17], Iceland [18], and the Antarctic; and for minke whales (B. bonaerensis) [19] [20] [21] [22]. Tp is useful for estimating age at sexual maturity, which is one of the most important biological parameters, and it can be used to monitor changes in this parameter within whale populations [15] [16] [19] [21] [23] [24]. However, the appearance and utility of $\mathrm{Tp}$ have not been clarified in common minke whales. Our objective here was thus to investigate the usability of $\mathrm{Tp}$ as a characteristic for estimating age at sexual maturity in the North Pacific common minke whale.

\section{Material and Methods}

We used readable earplugs obtained from 775 male and 206 female North Pacific common minke whales collected during the Japanese Whale Research Program under Special Permit in the western North Pacific JARPN (1994-1999) and JARPN II surveys (2000-2011). Sampled earplugs were preserved in $10 \%$ neutral buffered formalin solution. In the laboratory, the earplugs were cut flat along the central axis of the core using a blade according to Lockyer [8]. Then, the earplugs were ground on a wet stone to expose the neonatal line and the growth layers and to smooth the surface. The cut surfaces of the earplugs were then examined underwater using a stereomicroscope (Olympus SZX10). Age was determined by reading the growth layers appearing on the bisected surface of the earplug, assuming annual deposition of growth layers (one pair of dark and light laminae accumulate per year). We recorded $\mathrm{Tp}$ when we clearly identified the part that exhibited a sudden decrease in its spacing (Figure 2).

We also used biological data on the following morphological characteristics: body length, sex, skull width (measured at the largest part of the zygomatic process of the temporal bone), weight of testis, and number of ovulations. A male with a testicle weighing more than $290 \mathrm{~g}$ [25] and a female with at least one corpus luteum or albicans in her ovaries [2] were regarded as sexually mature.

\section{Results}

\subsection{Identification of Tp}

A visible $\mathrm{Tp}$ was observed in $43.5 \%$ of male North Pacific common minke whales and in $26.2 \%$ of females (Table 1 ). The appearance of $\mathrm{Tp}$ was related to 


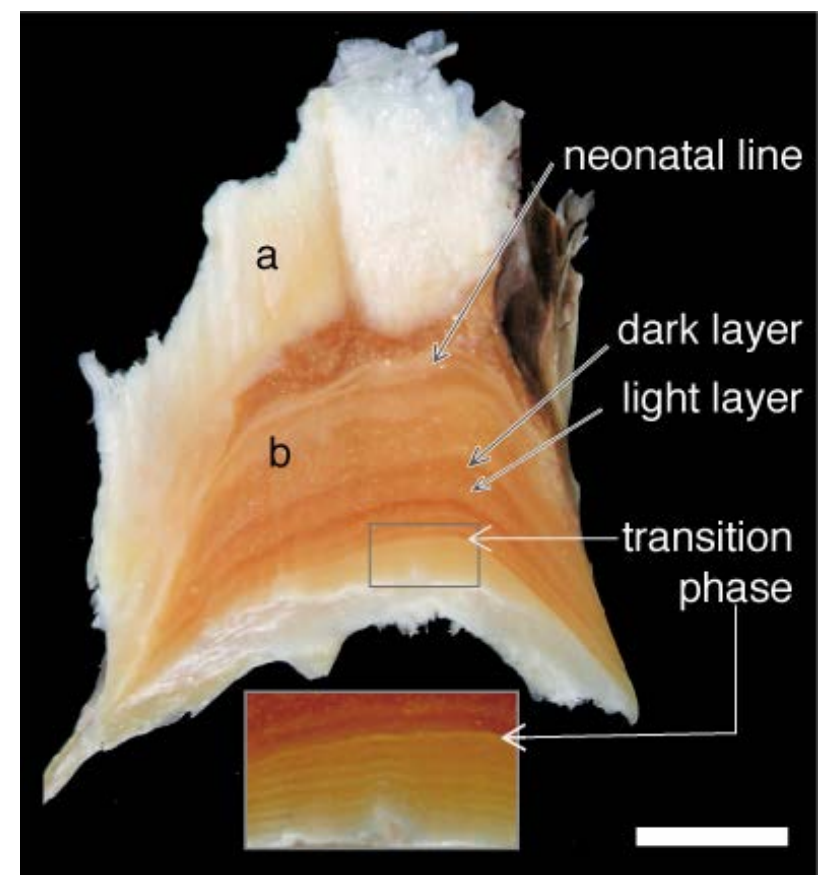

Figure 2. Bisected surface of a earplug of a North Pacific common minke whale (male, body length $=7.07 \mathrm{~m}$, age $=19$ year, age at $\mathrm{Tp}=6$ year), a: outer covering; b: core with growth layers, and magnified view (below) of the part at the transition. Scale bar: $5 \mathrm{~mm}$.

Table 1. Percentage of North Pacific common minke whales in which the transition phase (Tp) was observed, by sex.

\begin{tabular}{ccccc}
\hline & $n$ & With tp & Without tp & Recognition of Tp (\%) \\
\hline Male & 775 & 337 & 438 & 43.5 \\
Female & 206 & 54 & 152 & 26.2 \\
\hline
\end{tabular}

Table 2. Percentage of sexually mature North Pacific common minke whales based on reproductive organ morphology, by sex.

\begin{tabular}{ccccc}
\hline & $n$ & Immature & Mature & Sexual maturity rate (\%) \\
\hline Male & 775 & 144 & 631 & 81.4 \\
Female & 206 & 118 & 87 & 42.2 \\
\hline
\end{tabular}

maturity status; a higher proportion of females than males were immature (Table 2), and the majority of whales with a visible Tp were mature individuals (Figure 3 ). However, there were a few immature individuals with a visible $\mathrm{Tp}$ in both sexes (one male, three females). Examination of body length and age showed that the body lengths of immature whales exhibiting a Tp were larger than those of immature whales without a visible Tp (Figure 4), and the former tended to be older than the latter (Figure 5). The range of body length and age of immature whales with Tp overlapped those of mature ones. Tp was apparent in $53.2 \%$ of mature males and in $58.6 \%$ of mature females (Table 3 ). Figure 6 shows the relationship between age and presence of $\mathrm{Tp}$ in mature whales. Tp was more frequently observed in older whales of both sexes. Approximately $25 \%$ of 
whales from 4 to 11 years old had a visible Tp, and $>50 \%$ of whales more than 12 years old exhibited Tp. It was difficult to recognize Tp in mature whales that had recently attained sexual maturity.

\subsection{Age in Relation to Number of Ovulations and Skull Width}

The number of ovulations clearly increased with age after sexual maturation based on Tp (Figure 7). The relationship between age after maturation $(X)$ and number of ovulations $(Y)$ was estimated by linear regression as follows:

$$
Y=0.80 X+0.96
$$

The $X$ and $Y$ intercepts were 0 and 1, respectively, lending further credence to the view that $\mathrm{Tp}$ is a valid indicator of age at sexual maturity.

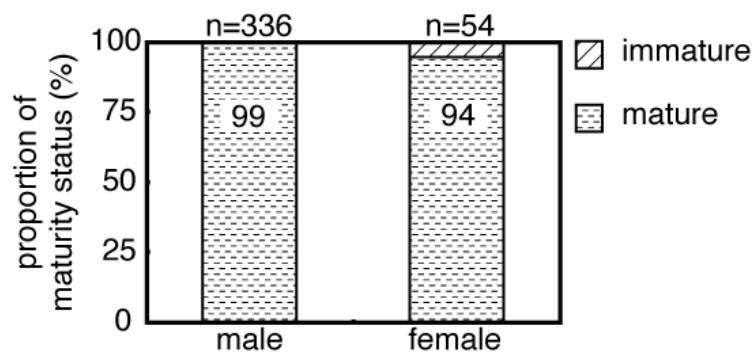

Figure 3. Percentage of North Pacific common minke whales with the transition phase that were sexually mature, by sex.

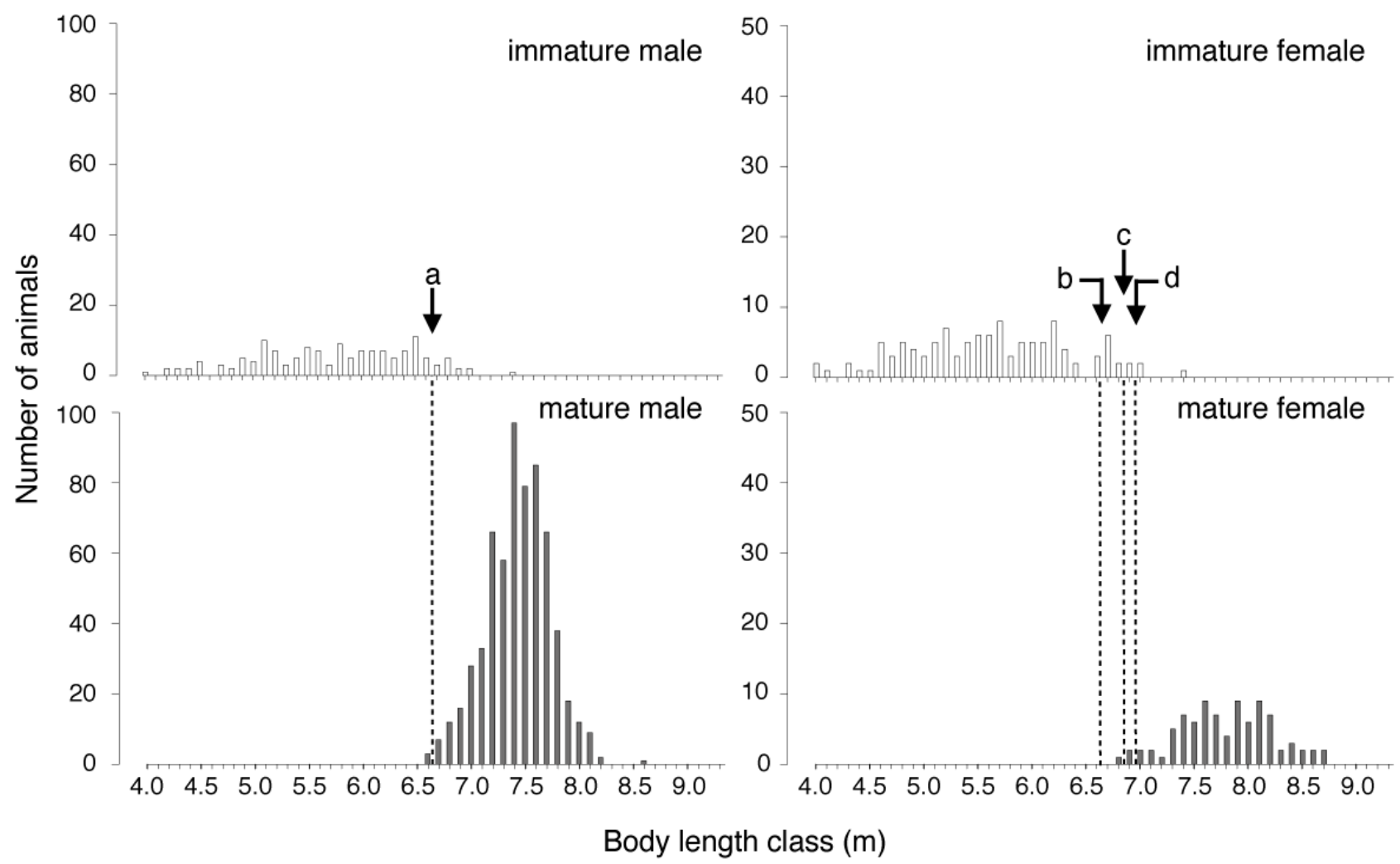

Figure 4. Body length of North Pacific common minke whales. Four whales had an observable transition phase (Tp); arrows and broken lines indicate these whales (a: $6.63 \mathrm{~m}$; b: $6.61 \mathrm{~m}$; c: $6.86 \mathrm{~m}$; d: $6.94 \mathrm{~m}$ ). 


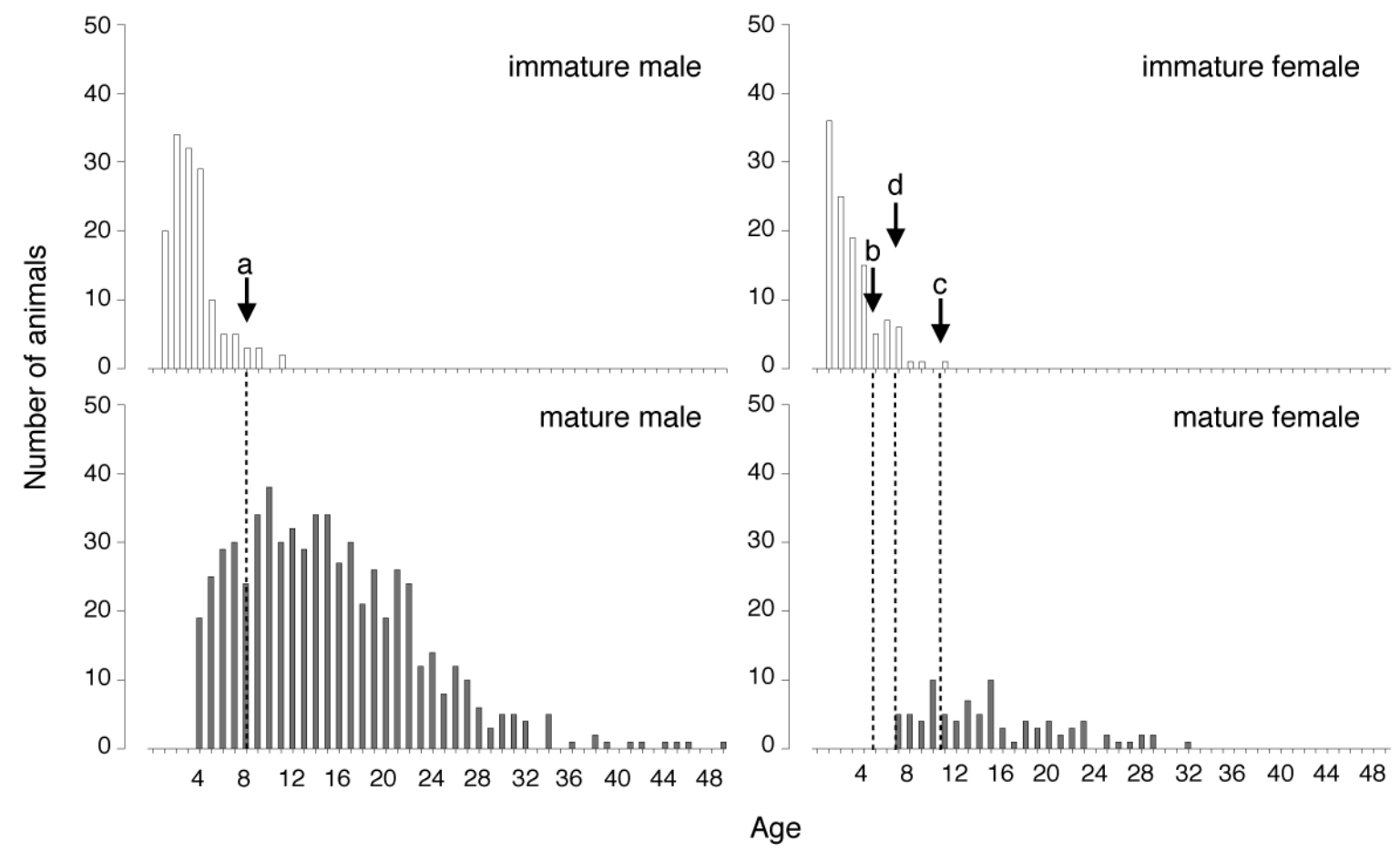

Figure 5. Age (years) of studied North Pacific common minke whales. Arrows and broken lines mark immature whales with an observable transition phase (a: 8 ; b: 5 ; c: $11 ; \mathrm{d}: 7)$.

Table 3. Percentage of mature North Pacific common minke whales in which the transition phase (Tp) was observed, by sex.

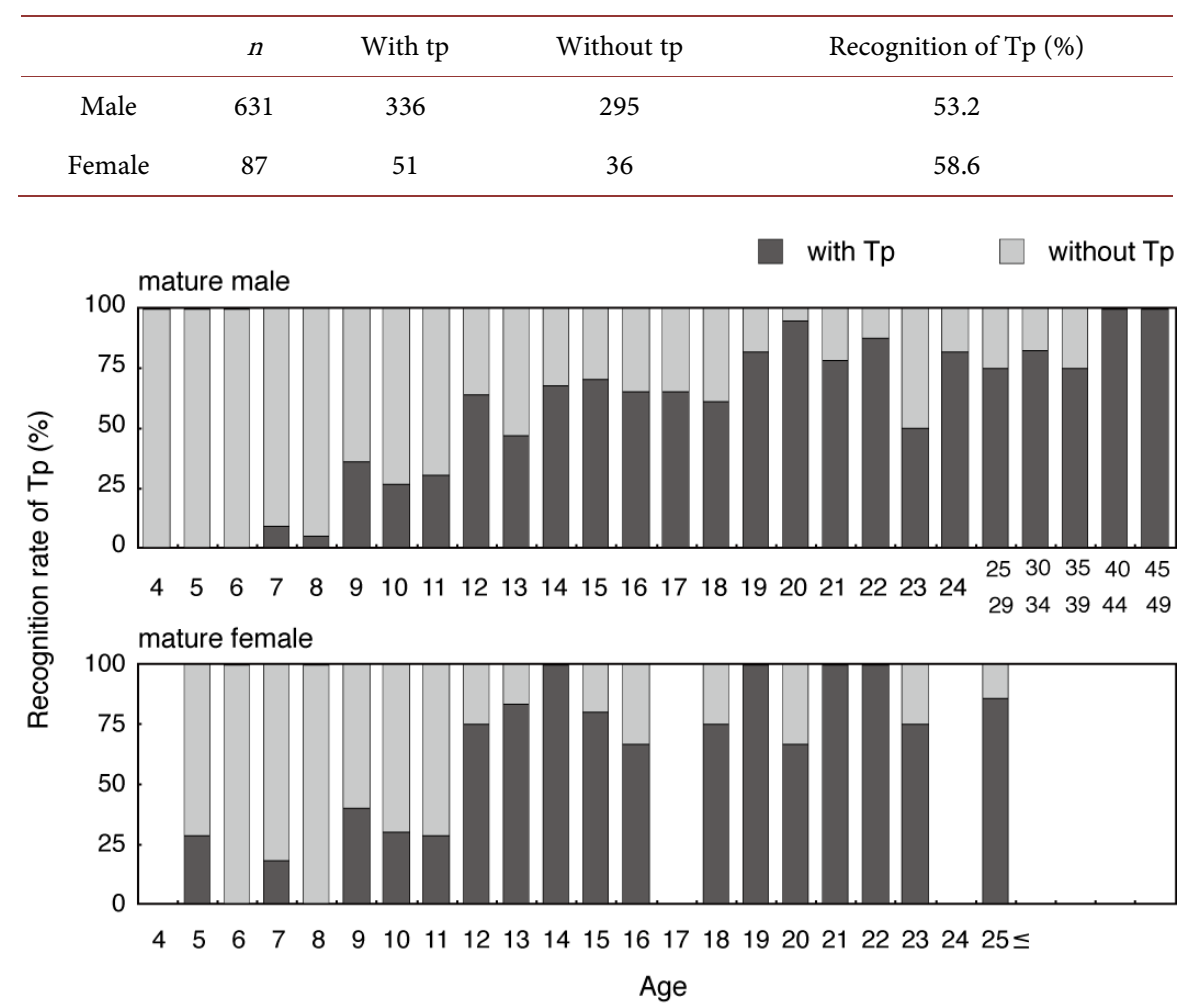

Figure 6. Relationship between age and visibility of transition phase (Tp) in mature male and female North Pacific common minke whales. 


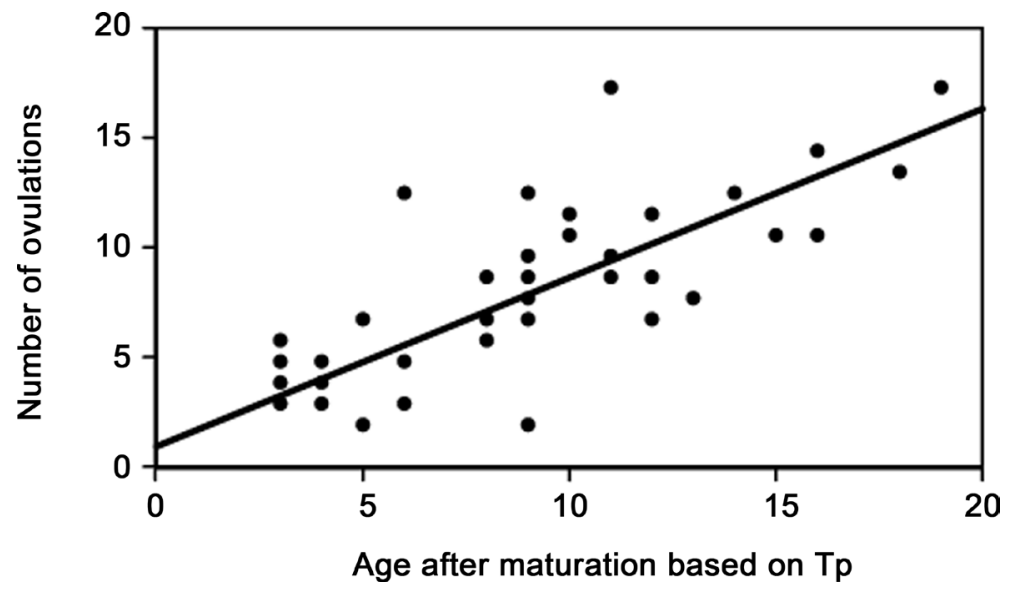

Figure 7. Number of ovulations according to age after sexual maturation based on the transition phase (Tp) $(n=42)$.

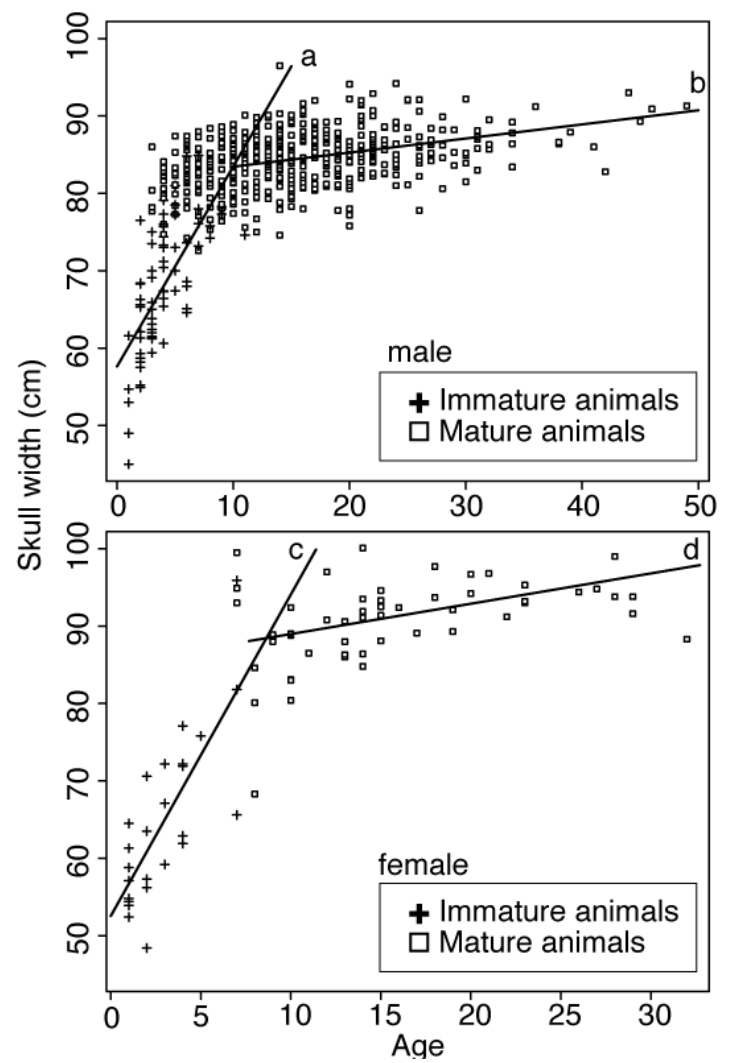

Figure 8. Skull width in relation to age of immature North Pacific common minke whales and mature whales in both sexes (male: upper, female: lower). Regression line: a: immature male, b: mature male, $c$ : immature female, $d$ : mature female.

The regression relationships ( $Y=$ skull width, $X=$ age) for each category were as follows (Figure 8):

Immature whales in males: $Y=2.86 X+56.72(\mathrm{R}=0.70)$

Mature whales in males: $Y=0.18 X+81.62 \quad(\mathrm{R}=0.39)$

Immature whales in females: $Y=4.15 X+52.54 \quad(\mathrm{R}=0.77)$

Mature whales in females $Y=0.39 X+85.02 \quad(\mathrm{R}=0.43)$ 
A significant difference was observed between the slope of the regression for immature and mature whales in both sexes (ANOVA test, $P<0.001$ ). Age at the crossing point of the regression line was 9.27 in males and 8.69 in females.

\subsection{Mean Age at First Ovulation and Age at Tp}

There were four females for which only one corpus luteum or albicans was observed in their ovaries; therefore, mean age at first ovulation was 8.75 years ( $S D$ $=1.5, \min =7, \max =10, n=4)$. Mean age at $\mathrm{Tp}$ in males was 7.68 year $(S D=$ 1.81 , $\min =4, \max =13, n=336)$, whereas that in females was 7.82 years $(S D=$ $1.58, \min =4, \max =11, n=51$ ).

\section{Discussion}

We found that the presence of $\mathrm{Tp}$ was related to the maturity status of $B$. acutorostrata and that most whales having a visible $\mathrm{Tp}$ were mature individuals, with a few exceptions. The presence of $\mathrm{Tp}$ in immature animals was previously reported in sei and Antarctic minke whales [13] [20] [21] [22]. Data on body length and age suggested the possibility that immature individuals exhibiting $\mathrm{Tp}$ had almost attained sexual maturity. We compared the presence of $\mathrm{Tp}$ in mature North Pacific common minke whales with that in other species (Table 4) [8] [13] [26]. Large proportions of fin and sei whale populations exhibited Tp. Dozens of males and females Antarctic minke whales, which are closely related to the common minke whale, also with showed the presence of $\mathrm{Tp}$. The reliability of identification of $\mathrm{Tp}$ in the common minke whale appears to be less than that in other whale species. We could not identify $\mathrm{Tp}$ in two cases of earplugs: those with growth layers with completely irregular or gradually diminished spacing. It is known that the general readability of common minke whale earplugs is low because of the unclear formation of growth layers [11] [27]. Regarding a earplug in which $\mathrm{Tp}$ could not be identified because of its gradually diminished spacing, Kato [21] reported a similar growth layer pattern in a earplug without $\mathrm{Tp}$ in an Antarctic minke whale. Furthermore, the core length of earplus is smaller in mature common minke whales than in other whales (Table 5); thus, it is considered that the interval of growth layers is originally narrow, which hampers the identification of $\mathrm{Tp}$ in this species. However, the present study revealed that $\mathrm{Tp}$ could be recognized in the North Pacific common minke whale.

Table 4. Percentage of North Pacific common minke whales in which the transition phase (Tp) was observed, among four species.

\begin{tabular}{lcccc}
\hline & $\begin{array}{c}\text { Fin whale Southern } \\
\text { hemisphere }\end{array}$ & $\begin{array}{c}\text { Sei whale } \\
\text { Southern } \\
\text { hemisphere }\end{array}$ & $\begin{array}{c}\text { Antarctic minke whale } \\
\text { Southern hemisphere }\end{array}$ & $\begin{array}{c}\text { Common minke } \\
\text { whale North } \\
\text { Pacific }\end{array}$ \\
\hline Mature male & $81-87$ & 88 & 61.8 & 53.5 \\
Mature female & $80-83$ & 86 & 60.0 & 58.6 \\
& Lockyer, 1972 & Lockyer, 1974 & Zenitani, 2011 & this study \\
\hline
\end{tabular}


Table 5. Mean core length $(\mathrm{cm})$ in mature whales among four species. The core length was measured from the neonatal line to the germinal layer.

\begin{tabular}{ccccc}
\hline Species & Mean & $S D$ & $n$ & \\
\hline Fin whale (Southern hemisphere) & 6.01 & 2.02 & 48 & (Maeda, in press) \\
Sei whale (North Pacific) & 2.07 & 1.00 & 68 & (Maeda, in press) \\
Antarctic minke whale & 2.04 & 1.02 & 234 & (Zenitani, 2011) \\
Minke whale (North Pacific) & 1.18 & 0.56 & 114 & (Maeda, in press) \\
\hline
\end{tabular}

It was found that the growth rate of skull width clearly changed in immature and mature whales in both sexes. Age at the inflection point of regression lines almost corresponds to the age at first ovulation. Mean age at $\mathrm{Tp}$ in both sexes was slightly lower than age at the crossing point of regression lines; however, in consideration of the range of age at which $\mathrm{Tp}$ appears, it is roughly appropriate. Therefore, formation of $\mathrm{Tp}$ in common minke whales was related to changes in the rate of skull growth, as was true for other species [13] [14]. Regarding the identification of $\mathrm{Tp}$ in mature whales, it was difficult to recognize $\mathrm{Tp}$ in younger whales that had recently attained sexual maturity. This difficulty may occur because too few layers were formed in the earplug to distinguish Tp clearly, resulting in a temporal lag in perception of Tp. Kato [21] and Ohsumi [22] reached similar conclusions, stating that $\mathrm{Tp}$ could be identified $4-5$ years after the attainment of sexual maturity. To avoid potential bias from this temporal lag in perception, the use of $\mathrm{Tp}$ to monitor changes in age at sexual maturity should be restricted to whales that are more than 12 years old after birth, the age at which $\mathrm{Tp}$ becomes reliably observable at a rate of more than $50 \%$.

\section{Conclusion}

In conclusion, we found that $\mathrm{Tp}$ could be identified in the North Pacific common minke whale. Most whales with an apparent Tp had attained sexual maturity. We also showed a significant correlation between the number of corpora and time after maturation in female minke whales. From these results, we concluded that $\mathrm{Tp}$ was a valid indicator for estimating age at sexual maturity in individual common minke whales. To date, earplugs of this species have been regarded as poor characteristics for evaluating age. However, we demonstrated that earplugs of common minke whales can reveal not only age, but also age at which sexual maturity was attained.

\section{Acknowledgements}

These findings were made possible by the well-organized, long-term research programs JARPN and JARPN II. This research was performed by the Institute of Cetacean Research and National Research Institute of Far Seas Fisheries. We thank all of the survey leaders for supporting this study. We also thank the crew of the research vessels and staff of the research station. 


\section{References}

[1] Lockyer, C. (1984) Age Determination by Means of the Earplug in Baleen Whales. Report of the International Whaling Commission, 34, 692-696.

[2] Lockyer, C. (1984) Review of Baleen Whale (Mysticeti) Reproduction and Implications for Management. Report of the International Whaling Commission, 6, 27-50.

[3] Purves, P. E. (1955) The Wax Plug in the External Auditory Meatus of the Mysticeti. Discovery Reports, 27, 293-302.

[4] Lillie, D.G. (1910) Observation on the Anatomy and General Biology of Some of Members of the Lager Cetacea. Proceedings of the Zoological Society of London, 80, 769-792. https://doi.org/10.1111/j.1096-3642.1910.tb01916.x

[5] Ichihara, T. (1959) Formation Mechanism of Ear Plug in Baleen Whales in Relation to Glove-Finger. Scientific Reports of the Whales Research Institute, 14, 107-135.

[6] Roe, H.S.J. (1967) Seasonal Formation of Laminae in the Ear Plug of the Fin Whale. Discovery Reports, 35, 1-30.

[7] Ohsumi, S. (1964) Examination on Age Determination of the Fin Whales. Scientific Reports of the Whales Research Institute, 18, 49-88.

[8] Lockyer, C. (1972) Maturity of the Southern Fin Whale (Balaenoptera physalus) Using Annual Layer Counts in the Ear Plug. ICES Journal of Marine Science, 34, 276-294. https://doi.org/10.1093/icesjms/34.2.276

[9] Gabriele, C.M., Lockyer, C., Straley, M.J., Jurasz, M.C. and Kato, H. (2010) Sighting History of a Naturally Marked Humpback Whale (Megaptera novaeangliae) Suggests Ear Plug Growth Layer Groups Are Deposited Annually. Marine Mammal Science, 26, 443-450. https://doi.org/10.1111/j.1748-7692.2009.00341.x

[10] Ichihara, T. (1964) Prenatal Development of Ear Plug in Baleen Whales. Scientific Reports of the Whales Research Institute, 18, 29-48.

[11] Maeda, H., Kawamoto, T. and Kato, H. (2013) A Study on the Improvement of Age Estimation in Common Minke Whales using the Method of Gelatinized Extraction of Earplug. NAMMCO Scientific Publications, 10, 17.

https://doi.org/10.7557/3.2609

[12] Maeda, H., Bnado, T., Kishiro, T., Kitakado, T. and Kato, H. (2016) Basic Information of Earplugs as Age Character of Common Minke Whales in Western North Pacific. Paper SC/F16/JR53 Presenter to the JARPN II Special Expert Panel Final Review Workshop, February 2016 (Unpublished), 15 p.

[13] Lockyer, C. (1974) Investigation of the Ear Plug of the Southern Sei Whale, Balaenopteraborealis, as a Valid Means of Determining Age. Journal du Conseil, 36, 71-81. https://doi.org/10.1093/icesjms/36.1.71

[14] Kato, H. (1983) Some Considerations on the Decline in Age at Sexual Maturity of the Antarctic Minke Whale. Report of the International Whaling Commission, 33, 393-399.

[15] Lockyer, C. (1977) A Preliminary Study of Variations in Age at Sexual Maturity of the Fin Whale with Year Class in Six Areas of the Southern Hemisphere. Report of the International Whaling Commission, 27, 141-147.

[16] Lockyer, C. (1981) The Age at Sexual Maturity in Fin Whales off Iceland. Report of the International Whaling Commission, 31, 389-393.

[17] Masaki, Y. (1976) Biological Studies on the North Pacific Sei Whale. Bulletin Far Seas Fisheries Research Laboratory, 14, 1-104. 
[18] Lockyer, C. and Martin, A.R. (1983) The Sei Whale off Western Iceland. II. Age, Growth and Reproduction. Report of the International Whaling Commission, 33, 465-476.

[19] Masaki, Y. (1979) Yearly Changes of the Biological Parameters for the Antarctic Minke Whale. Report of the International Whaling Commission, 29, 225-251.

[20] Best, P.B. (1982) Seasonal Abundance, Feeding, Reproduction, Age and Growth in Minke Whale off Durban (with Incidental Observations from the Antarctic). Report of the International Whaling Commission, 32, 759-786.

[21] Kato, H. (1985) Further Examination of the Age at Sexual Maturity of the Antarctic Minke Whale as Determined from Earplug Studies. Report of the International Whaling Commission, 35, 273-277.

[22] Ohsumi, S. (1986) Earplug Transition Phase as an Indicator of Sexual Maturity in Female Antarctic Minke Whales. Scientific Reports of the Whales Research Institute, 37, 17-30.

[23] Lockyer, C. (1979) Changes in a Growth Parameter Associated with Exploitation of Southern Fin and Sei Whales. Report of the International Whaling Commission, 29, 191-143.

[24] Kato, H. and Sakuramoto, K. (1991) Age at Sexual Maturity of Southern Minke Whales: A Review and Some Additional Analyses. Report of the International Whaling Commission, 41, 331-337.

[25] Kishiro, T., Kato, H., Yoshida, H., Yasunaga, G., Tabata, S., Nakamura, G., Maeda, H., Inoue, S., Miyakawa, N., Okamoto, R., Oikawa, H., Watanabe, H., Iwasaki, T., Kanaji, Y., Minamikawa, S., Otani, H., Ishikawa, H., Kanda, N., Gokita, A., Yamazaki, K. and Yonehara, Y. (2010) Cruise Report of the Second Phase of the Japanese Whale Research Program under Special Permit in the Western North Pacific (JARPN II) in 2009 (Part 2)-Coastal Component off Kushiro. Paper SC/62/O6 Presented to the 62nd IWC Scientific Committee Meeting, 13.

[26] Zenitani, R. (2011) Long-Term Change of the Age at Sexual Maturity and Ecological Analysis in Antarctic Minke Whale. Dr. Scient Thesis, Tokyo University of Marine Science and Technology, 106. (In Japanese)

[27] Kato, H. (1992) Body Length, Reproduction and Stock Separation of Minke Whales of Northern Japan. Report of the International Whaling Commission, 42, 443-453. 